\title{
The Portrayal of the Suffering of Socially Denigrated, Suppressed and Silenced Class in Indian Fiction
}

\author{
Aastha Pratap \\ Research Scholar \\ India \\ aasthapratap16@gmail.com
}

All men are equal but some

Men are more equal than others.....

George Orwell

(Animal Farm, 1945)

\begin{abstract}
These lines are more appropriate to the present day. It's a time when India is emerging as economic power, globalized culture and trends but still there lies an abominable and harrowing portrait of caste system behind this glittering appearance. It is so appalling that despite of 69 years of freedom from the clutches of imperialism, we are not yet free from our own social vices of stigmatizing the people belonging to the so called "lower classes". It's the harsh reality of our society that even in this $21^{\text {th }}$ century there are some people called "Dalits or Untouchables", who face discrimination, violence, and oppression from the higher castes or traditional upper classes particularly in access of jobs (works), education, health care, property and marriages etc. They are discriminated socially, economically, even in the matter of religion also. This paper intends to throw some light on the sordid saga of Dalit's plight and their
\end{abstract}


DOI: https://doi.org/10.24113/ijellh.v8i1.10411

frequent subjection to oppression, silence to violence and marginalization. Their voice was suppressed so long, their rights has been violated, they are denied to access to land and forced to work in degrading conditions, also they are abused by police and upper- caste society routinely. Though things have changed with the flow of time but still dalits are suffering in many ways, which will be highlighted in this paper with the help of some fiction in Indian literature.

Keywords: Dalit and Dalit literature, Untouchablity, Suppression (Oppression) and Discrimination.

Before dealing with the plight of Dalits, we must know about the caste system and the concept of dalit in our society. The caste system is determined by birth not by race, it was originated around 7 A.D. and it is based upon Hindu belief that a person's place and position in this life, is determined by the good deeds and sins of his previous life. In Hindu religion there are four major castes and each caste has specific rights and duties. These four castes are respectively: Brahmins (priests and intellectuals), Kshatriya (warriors), Vaishyas (artisans and traders), Shudras (servants). Dalits belongs to last category of caste which is to perform menial tasks or we can say that they are so low people that they are outside of this caste system and considered outcastes. Dalit means " broken people", they were outcastes also known as untouchables. As dalits are the members of the lowest caste of the society, they are supposed to do the spiritually condemning works that nobody else want to do, like preparing bodies for funerals, removing the waste of animals and humans, sweeping and cleaning the dirt of the higher castes and other menial tasks. They are supposed to be unclean and impious, that's why they are not allowed to enter into Hindu temples and sacred places. These people were not given the right of education and banned from a; the activities of higher castes. Even Dalits were not allowed to live in the villages, they were compelled to live outside the village boundaries, and they were also not allowed to take water from the common source of water like well, as 
DOI: https://doi.org/10.24113/ijellh.v8i1.10411

their touch would taint the water for others. Even if someone from higher caste is approaching towards them, they were supposed to bend themselves and prevent even their unclean shadows from touching him. The mere touch of a Dalit was considered "polluting" to a high caste member, thus the concept of "Untouchablity" was born. Here we can see that dalit caste faced discrimination in every facet of life, they had been suppressed so long.

Though things have changed now days but even now also we need a change in our society as Dalits are still suffering in many ways. We usually witness and hear many incidents of the exploitation of lower class in our society. Though the government took some steps for the welfare and equality of such people, like The Civil Act of 1955 and The Scheduled Castes and Tribes Act of 1989. The National Commission of Scheduled Castes and Tribes was also formed to protect their rights in the society but such efforts have failed to produce a positive change in our society. This caste system is like a curse for our society where we are not able live without any discrimination, despite of constitutional and legal efforts of making everyone equal, still this discrimination is existing in our society, still they are abused and tortured. Even now they are not getting the rights of proper education, employment, property and housing rights. They are the victim of violence at many places.

Our Indian literature has given proper place to the portrayal of their pain and suffering. Though here also they were discriminated as their portrayal was quite different from their actual life, that's why they raised their voice against it and Dalit literature was emerged to give them a platform or a voice to their long prevailed silent suffering. We can correlate it with subaltern theory of post colonialism. In post colonial terms "Everything that has either limited or no access to the cultural imperialism is subaltern"- means someone who is marginalized and oppressed. The Subaltern theory deals with the perspective of the "other"- Other means who is different and had no voice because of his class, race or gender, it is based on the theory of deconstruction and emphasized that the rules are established by those in power and imposed 
DOI: https://doi.org/10.24113/ijellh.v8i1.10411

on other. Gayatri Spivak, a postcolonial theorist emphasized on this concept of "other". In her work "Can the Subaltern Speak"- she simply mentioned that it is not possible for "others" to speak because they do not have voice or right to speak as they are marginalized by the powerful classes, moreover they are also divided by gender, race and all, so they can't stand together. So it is impossible for them to speak up, hence they won't be able to express their pain and suffering and that's why nobody can understand their world and problems. Because only they know the reality of their world and the people from other world or class won't be able to give a true portrayal of their world as they are not the part of it. Similarly in literature nobody else can give a true portrayal of the Dalits except them, because others are not having any idea of their suffering, so usually they misinterpret their concepts and problems. Hence some Dalits started writing to give a real portrayal of their problems. Here I would like a give a glimpse of the picture of Dalits in our Indian fiction with the reference of some short stories and novels.

First and formost I would like to give a reference of the short story The Poisoned Bread written by Bandhumadhv in Marathi language. It was translated by Ramesh Dnyate. This is the story of a mahar (outcaste) of Kupad village, named Yetalya Aja. It is harvesting season and Yetalya's grandson came to Kupad to visit him in his holidays. These mahars were poor and miserable. They used to work in the fields of the landowners who never treat them like a humans. They abused them, beat them and exploit them in every possible way. They were treated like animals and sometimes even worse than animals. In harvesting season Yetalya along with his grandson went to Bapu Patil, a landowner, in search of some work to get some corn and jawar to feed his family. He pleaded to Bapu Patil to give him some work in a very meek tone:

"I am Your slave Anna, I have to come to you on purpose on hearing of the operations at your thrashing floor. My lord you are our bread -giver and we find it a 
DOI: https://doi.org/10.24113/ijellh.v8i1.10411

privilege to beg for our share of corn. Master, I am your begging mahar and feel proud to do so.”

( The Poisoned Bread, 168)

Here we can see the plight of Yetalya how he is pleading for work before an insolvent and rich landlord. Even after such a request Bapu Patil did not moved and became sarcastic and said:

"You are no longer Mahars - Mangs of good old days, to beg your share of the corn. You are Harijans now, You have even started claiming equality."

( The Poisoned Bread, 168)

It shows that Patil is not happy with the rising voice of Mahars for equality as he feels that they will lose their power and rights to exploit these poor mahars.he further accused them for polluting the Gods and the rivers by entering in the temples. He accused them for profaning religion, abandoning caste and defiled the temple of Lord Vithoba of Pandharpur. He added that river Chandrabhanga is drying up because they have polluted it by their touch.

The Narrator who was the grandson of Yetalya, was brought up in city so he could not tolerate the insult of his grandfather. He raised his voice against this unjust and simply asked to Patil:

“Patil, will you kindly tell me what you meant when you accused us of forgetting our religion and caste and of polluting the God? And if a religion can't tolerate one human being treating another simply as a human being, what's the use of such an inhumane religion? And if our touch pollutes the Gods, why were the Mahars and 
DOI: https://doi.org/10.24113/ijellh.v8i1.10411

Mangs created after all? Who have create dthem and can you pleae tell me the name of any God whom the Mahras and Mangs can claim as their own?"

(The Poisoned Bread, 168)

We can see that the grandson raised question on the entity of God and the double standard of this society. but Patil felt offended and said:

“A Mahar will be Mahar even if he passes L.L.B. and becomes a barriestor. One should always keep to one's Position

A chappal is never worshipped in place of God" (TPB, 169)

Yetalya apologized to Patil and satisfied his false ego with his plea and begged some work. Here we find a clash of generations of the people. Now when people are educated they are trying to speak against the unjust but still he old generation can't even think of going against those rigid high caste people, that's why people like Patil takes advantage of them. Patil asked them to work in the field under the hot sun without any rest. Yetalya went to fetch some corn from nearby; the grandson was left alone to work there. Meanwhile Bapu Patil arrived there with Tuka Magdoom and start abusing his grandfather in the most humiliating way. Again there was a heated argument between them and Patil kicked out both of them without any share of jawar and corn. He bullied them and they leave without saying anything. Before leaving Yetalya looked at some stale rancid pieces of bread lay scattered on the ground in front of the oxen and he pleaded to Patil to get those crumbs. They were smeared with dung and urine of oxen, but Yetalya collected them happily and put them into his sackcloth and left the place but not without giving blessings to Patil. Yetaltya was upset as he was not able to earn anything today to feed his family and his grandson was annoyed with him for taking those pieces of 
DOI: https://doi.org/10.24113/ijellh.v8i1.10411

bread. The grandson tried to convince his grandfather that if we keep begging to them, they will become the slaves of them and they will keep oppressing them without any reason. They also have right to abandon, at this yetalya get convinced and he threw those pieces to the dogs outside their home. At this moment his wife came out risiing of the house and shouted on him, has he gone mad? If they will throw these crumbs to dogs what will they eat? She collected all the pieces and cleaned them, mixed them with dhulli and cooked them for supper. But the next morning The grandfather was vomiting, the doctor told that it was food poisoning and his condition is critical. The food turned into poison for him as he realized that it was not worth of eating. Yetalya uttered his final words to his grandson:

"Never depend on the age -old bread associated with our caste. Get as much education as you can. Take away this accursed bread from the mouths of the Mahars. This poisonous bread will finally kill the very humanness of man....." (The Poisoned Bread, 174)

The narrator lost his grandfather because of that food poisoning, through this story we can see the plight of the Mahars. We saw how they were discriminated and abused by others; they even did not get proper food to eat and were compelled to die if they try to satisfy their belly. They were assaulted and abused by the wealthy landowners.

There is another short story The Storeyed House which is another example to show the agony of dalits. This was written by Woman Hoval. Again this is the story of an outcaste, Bayaji who just got retirement after the service of thirty five years and now comes back to his village to live his life in peace. But it was not easy for him as he was an outcaste, he faced a harsh criticism and discrimination in his life because he was a Mahar and now when he is coming back to settle he faced many problems. While he was on his way, he met Bhujaba, a rascal of village. Byaji simply greeted him: 
"Greetings to you sir, How are things with you?"

This was a kind of humiliation for Bhujaba because Bayaji was a Mahar by caste and according to the old customs he should have greeted him in traditional way like:

“My humble salutations to you sir, who are my father and mother" So when Bayaji simply greeted him he was furious and replied:

"Do you think that you can become a Brahmin merely by saying greeting? Can you forget your position simply because you have turned into a Buddhist?" (179)

Through these lines we came to know about the attitude of the people of upper class. Another fact which we need to notice here is the conversion of Dalits, either to Christianity or to Buddhism. In Hinduism, they are not treated equally so they turned to other religions to get an equal place but they were cheated there also as nobody accepts them equally. Here also Bayaji turned to Buddhism in quest of identity and equality. Bayaji wanted to thrash Bhujba but he could not afford it as he was a Mahar. He pleaded to him in a submissive tone that don't do this to him as he returned here to live till the end of his life later he moved to his place Takkya- the untouchables settlement- this place was out of the village for outcaste people. It is named Buddha Vihar by those who embraced Buddhism to avoid their own identity. Baya Ji was welcomed by his family and he revealed his plan to make a storyed house of three portions from his retirement's fund. 
DOI: https://doi.org/10.24113/ijellh.v8i1.10411

The news of building a storyed house by a mahar was spread in the village like a flame as it was unacceptable for the higher class of the village. There was just one storyed house belonged to Kondiba Patil, now Bayaji was his rivaland he simply asked him:

"Do you aspire to get an equal status with us by building this house? One should keep to one's position. You shouldn't let a little money turn your head.”(180)

Bayaji simply replied in a very humble way that I just wanted to build a shelter for family. Kondiba warned him to quit this plan id he wanted to live in this village. It shows that the Dalits are even not allowed to have a good house, they are not allowed to have a dream of beautiful house. When the house was complete, the housewarming ceremony was planned and relatives and villagers were invited. The false ego of the kondiba, Bhujba nd others was not allowing this, they felt humiliated as if they were saying:

"This untouchable worm has got a swollen head. He needs proper handling." (182)

When the celebrations were going on Bayaji's new storeyed house caught fire from all the sides.it crashed down in front o Bayaji's eyes, he was burnt all over and was in great agony. His son asked him his last desire he simply said "I want you to build a storeyed house" and he died in pain. His entire family was shattered with this calamity and in the next morning village officers visited the place to make a record of the accident and they simply conclude that it was because of a petromax flare-up. Bayaji who wanted to live a comfort retired life was resting in cemetery.

Here we can say that Dalits are exploited severely they are not allowed to live their life according to them. Byaji's dream of a storeyed house was shattered into pieces. And he was 
DOI: https://doi.org/10.24113/ijellh.v8i1.10411

burnt alive along with his new house because he tried to do something against the wish of higher class of village.

Chauthi Bhint (The Fourth Wall) by Urmila Panwar is the another story I would like to mention here. It was translated by Gail Omvedt. It is the story of Pandurang Medhakar (Nana), who got retired from postal service. His Sons planned a celebration for his retirement party as well as for Dr. Babashahab Ambedkar Cultural Centre, started by their friend. Through this programme they wanted introduce this centre . nana was an ordinary man who always faced a harsh criticism in his life but that day he was highly praised by others. They addressed him as "a servant of society" and "Great Benefactor" etc. After hearing such words for himself, he remind Ambekar, Savarkar and Phule and Nana realized that he must do something for the welfare of the society and he announced that he will donate his retirement fund of fifty thousand rupees to the cultural centre. He felt gratified and satisfied but his children were annoyed because of this step. Soon he was compelled to leave the house, he went to old age. He shared his room with three persons named Savant Rasal and Joshi who were belonging to high caste of the society. Unaware of Medhakar's caste they treated him well as they all were homeless and companions to each other. There were four walls in the room, each of them occupied one wall, and there they had pasted the pictures of Gods and Goddesses. They asked Nana to take the fourth wall and decorate it with his posters, but he remained silent because he knew once they will get to know about his caste, they will abandon him. Exactly the same thing happened with hi, when they all get suspicious about his caste they started ignoring him Again Nana was left alone, alter he moved to his village with his aunt who came to meet him and take him away with her, before leaving the place Nana pasted the poster of Ambedkar Sahab on that fourth wall. That shows his courage to accept his identity. In this story we find the double standards of society as people are dual here. They are false and hollow like Nana's children and his 
DOI: https://doi.org/10.24113/ijellh.v8i1.10411

roommates ate the old age home. Nana was compelled to leave his own house and later on that old age home also as everybody was ignoring him because he was an outcaste. Through the character of Nana we should try to understand that we can't escape from our reality, we need to accept our identity and face the world confidently.

In Indian literature we can find many other works which portrayed the harshness of the world of Dalits. The Untouchable is one of the finest examples of such works. It was written by Mulkraj Anand in 1935, it deals with the story of an outcaste, Bakha. The novel depicts just one day of his life, which shows the hardships of Bakha and his family.he is a sweeper and his day strats with his father's anger at him, as he had to go to clean the latrines of the high caste men. Everybody yelled at him, he finished his morning duty and goes to home to have some water, but his only sister was out to fetch some water from the well. There she was bullied by some women but helped by the priest Pandit Kali Nath, he asked her to come to clean the temple, later she was sexually assaulted by the Pandit when she resists, he accused her of polluting the temple. Bakaha saved a young boy but there also he was abused. In the end he finds some solace in the specch of Mahatma Gandhi ji. Through this novel we see that the suffering of outcastes. Another example can be of The God of the Small Things by Arundhati Roy. This was the story of Syrian Christian family in Ayemenem.mainly this was the story to two fraternal twins whose lives were destroyed by "Love Laws". There is a character named Velutha, who is a Paravan (Untouchable). He works in "The Paradise Pickles Factory" of Mamachi. He is the most skilled employee of the factory but he is always paid low wages as he was a lower man. His Father Vallya Papen mentions that their ancestors used to walk with a broom tied to their wais to remove their footprints from the ground. Mere a touch of these people could pollute the things. Velutha is the worst sufferer in the novel, he was brutally assaulted by the police which lead him to death. The only fault of Velutha was that he fell in 
DOI: https://doi.org/10.24113/ijellh.v8i1.10411

love with Ammu who was an upper caste lady. They were not allowed to love as Velutha was a paravan. Ammu was locked at home and Velutha gets arrested for false accusations anf physically assaulted by the police and he got a tragic death. He was tortured to that extent because he was an untouchable and he was an active member of communist party which was leading some protests for equality. Munshi Premchand's novels and short stories also give a pathetic portrayal of lower class which is actually a true portrayal of our Indian society.

Now after analyzing these fictional works, we come across the reality of caste system. We can see how Dalits are suffering. They are not allowed to raise their voice, if they try to say anything there is voice is suppressed. Though things have changed but still discrimination is not ended yet. They are facing problems everywhere this was just a glimpse of the reality, hence it is really horrible. They suffers from routine violations of their rights, in that case Dalit women are the worst sufferer. They face additional discrimination and violence. We usually see many news related to the exploitation of them. Even the children of Dalits are not allowed to sit with other students; they are bullied by fellow classmates as well as teachers on the name of caste. At some places there are even treated worse than the animals that is very pathetic. We need to think about this caste system. In 2006, Former Indian Prime Minister Manmohan Singh called this Untouchablity a "Hidden Apartheid". Even Gandhi Ji raised voice against this discrimination and he called Dalits "Harijan" that means 'Hari- ke- jan'- one who is loved by the God (Hari). This caste system is like a curse for any country and we need to think about it. 
DOI: https://doi.org/10.24113/ijellh.v8i1.10411

Work Cited

Dangle Arjun, Poisoned Bread: Translations from Modern Marthi Dalit Literature, 